\title{
Serum albumin and beta-amyloid deposition in the human brain
}

Jee Wook Kim, MD, PhD, Min Soo Byun, MD, PhD, Jun Ho Lee, MD, Dahyun Yi, PhD, So Yeon Jeon, MD, Bo Kyung Sohn, MD, Jun-Young Lee, MD, PhD, Seong A Shin, MS, Yu Kyeong Kim, MD, PhD, Koung Mi Kang, MD, Chul-Ho Sohn, MD, PhD, and Dong Young Lee, MD, PhD, for the KBASE Research Group

Neurology ${ }^{\circledR}$ 2020;95:e815-e826. doi:10.1212/WNL.0000000000010005

\section{Abstract \\ Objectives}

To investigate the relationships of serum albumin with in vivo Alzheimer disease $(\mathrm{AD}) \mathrm{pa}-$ thologies, including cerebral $\beta$-amyloid $(\mathrm{A} \beta)$ protein deposition, neurodegeneration of $\mathrm{AD}$ signature regions, and cerebral white matter hyperintensities (WMH), in the human brain.

\section{Methods}

A total of 396 older adults without dementia underwent comprehensive clinical assessments, measurement of serum albumin level, and multimodal brain imaging, including $\left[{ }^{11} \mathrm{C}\right]$ Pittsburgh compound B-PET, ${ }^{18}$ F-fluorodeoxyglucose-PET, and MRI. Serum albumin was categorized as follows: $<4.4 \mathrm{~g} / \mathrm{dL}$ (low albumin), 4.4 to $4.5 \mathrm{~g} / \mathrm{dL}$ (middle albumin), and $>4.5 \mathrm{~g} / \mathrm{dL}$ (high albumin; used as a reference category). $\mathrm{A} \beta$ positivity, $\mathrm{AD}$-signature region cerebral glucose metabolism $(\mathrm{AD}-\mathrm{CM}), \mathrm{AD}$-signature region cortical thickness $(\mathrm{AD}-\mathrm{CT})$, and $\mathrm{WMH}$ volume were used as outcome measures.

\section{Results}

Serum albumin level (as a continuous variable) was inversely associated with $A \beta$ deposition and $\mathrm{A} \beta$ positivity. The low albumin group showed a significantly higher $\mathrm{A} \beta$ positivity rate compared to the high albumin group (odds ratio $3.40,95 \%$ confidence interval 1.67-6.92, $p=0.001$ ), while the middle albumin group showed no difference (odds ratio $1.74,95 \%$ confidence interval $0.80-3.77, p=0.162$ ). Neither serum albumin level (as a continuous variable) nor albumin categories were related to $\mathrm{AD}-\mathrm{CM}, \mathrm{AD}-\mathrm{CT}$, or $\mathrm{WMH}$ volume.

\section{Conclusions}

Low serum albumin may increase the risk of $\mathrm{AD}$ dementia by elevating amyloid accumulation. In terms of $\mathrm{AD}$ prevention, more attention needs to be paid to avoid a low serum albumin level, even within the clinical normal range, by clinicians.

\author{
Correspondence \\ Dr. Lee \\ selfpsy@snu.ac.kr
}




\section{Glossary}

$\mathbf{A} \boldsymbol{\beta}=\beta$-amyloid $\mathbf{A D}=$ Alzheimer disease $\mathbf{A D}-\mathbf{C M}=\mathrm{AD}$-signature cerebral glucose metabolism; $\mathbf{A D}-\mathrm{CT}=\mathrm{AD}$-signature cortical thickness; AMBAR = Alzheimer's Management by Albumin Replacement; $\mathbf{C N}=$ cognitively normal; FDG $={ }^{18} \mathrm{~F}$ fluorodeoxyglucose; FLAIR = fluid-attenuated inversion recovery; KBASE = Korean Brain Aging Study for Early Diagnosis and Prediction of Alzheimer's Disease; $\mathbf{M C I}=$ mild cognitive impairment; $\mathbf{M C L}=$ minimum cost of living; $\mathbf{M R}=$ magnetic resonance; PiB = Pittsburgh compound B; ROI = region of interest; SUVR = standardized uptake value ratio; $\mathbf{W M H}=$ white matter hyperintensities.

Alzheimer disease $(\mathrm{AD})$ is characterized by extracellular deposition of $\beta$-amyloid protein $(A \beta)$ and intraneuronal neurofibrillary tangles in the brain. ${ }^{1}$ Because $\mathrm{A} \beta$ deposition is the earliest pathology of $\mathrm{AD}$ and begins $\approx 10$ to 15 years before the onset of the cognitive symptoms, ${ }^{2-4}$ identification of factors affecting cerebral $A \beta$ deposition may facilitate the development of strategies for preventing $\mathrm{AD}$ dementia.

Serum albumin, which is the most abundant protein in human plasma, ${ }^{5}$ is regarded as one of the most potent $A \beta$ sequestering systems in that it binds $90 \%$ to $95 \%$ of the $A \beta$ in blood plasma. ${ }^{6,7}$ The dynamic equilibrium of $A \beta$ between brain and blood plasma may be shifted toward the bloodstream by peripheral serum albumin that binds the $A \beta{ }^{8}$ Therefore, a reduction in $A \beta$ binding to serum albumin in the blood may lead to a decrease in the capacity for $A \beta$ excretion from the brain to the blood, resulting in $A \beta$ deposition in the brain. ${ }^{9}$

Preclinical studies suggested that serum albumin may inhibit $A \beta$ fibril formation by binding $A \beta$ monomers ${ }^{7}$ or oligomers. ${ }^{10}$ Several human studies have indicated that a low serum albumin level is associated with cognitive impairment ${ }^{11-13}$ and $\mathrm{AD}$ dementia. ${ }^{14,15}$ However, little information is available on whether serum albumin is related to $A \beta$ deposition in the living human brain. Therefore, the present study was performed to examine the relationships of serum albumin and in vivo cerebral $A \beta$ deposition in older adults without dementia. We additionally investigated the associations of serum albumin with $\mathrm{AD}$-signature neurodegeneration and white matter hyperintensities (WMH) as a measure of cerebrovascular injury. While some human studies have reported an inverse association of serum albumin and cerebrovascular disease, ${ }^{16,17} \mathrm{few}$ studies have investigated the relationships of serum albumin with neurodegenerative changes in the brain.

\section{Methods}

\section{Participants}

The present study was performed as part of the Korean Brain Aging Study for Early Diagnosis and Prediction of Alzheimer's Disease (KBASE), which is an ongoing prospective cohort study. ${ }^{18}$ As of November 2016, a total of 396 older adults without dementia (284 cognitively normal [CN] individuals and 112 individuals with mild cognitive impairment $[\mathrm{MCI}])$ between 55 and 90 years of age were enrolled in the study. The $\mathrm{CN}$ group consisted of participants with a Clinical Dementia Rating ${ }^{19}$ score of 0 and no diagnosis of MCI or dementia. All individuals with MCI met the current consensus criteria for amnestic MCI, which are as follows: (1) memory complaints confirmed by an informant, (2) objective memory impairments, (3) preserved global cognitive function, (4) independence in functional activities, and (5) no dementia. With regard to criterion 2, the age-, education-, and sex-adjusted $z$ scores for at least 1 of 4 episodic memory tests were $<-1.0$. The 4 memory tests were the Word List Memory, Word List Recall, Word List Recognition, and Constructional Recall tests, which are included in the Korean version of the Consortium to Establish a Registry for Alzheimer's Disease neuropsychological battery. ${ }^{20}$ All individuals with MCI had a Clinical Dementia Rating score of 0.5. The exclusion criteria were as follows: (1) presence of a major psychiatric illness; (2) significant neurologic (e.g., cerebrovascular disease) or medical conditions that could affect mental function; (3) contraindications for MRI (e.g., pacemaker or claustrophobia); (4) illiteracy; (5) presence of significant visual/hearing difficulties or severe communication or behavioral problems that would make clinical examinations or brain scans difficult; (6) taking an investigational drug; and (7) pregnant or breastfeeding. The presence of any item included in the exclusion criteria was determined by research clinicians referring to the results of laboratory examinations and MRI and the clinical data collected by trained nurses during systematic interviews of participants and their reliable informants during the screening period. More detailed information on the recruitment of the KBASE cohort is presented in a previous report from our research group. ${ }^{18}$

\section{Standard protocol approvals, registrations, and patient consents}

This study protocol was approved by the Institutional Review boards of the Seoul National University Hospital (C-1401027-547) and SMG-SNU Boramae Medical Center (26-2015$60)$, Seoul, South Korea, and the study was conducted in accordance with the recommendations of the current version of the Declaration of Helsinki. The subjects or their legal representatives gave written informed consent.

\section{Clinical assessments}

All participants underwent comprehensive clinical and neuropsychological assessments administered by trained 
Table 1 Participant characteristics ${ }^{a}$

\begin{tabular}{|c|c|c|c|c|}
\hline Characteristic & Overall $(n=396)$ & $A \beta / A D-C M(n=388)$ & $A D-C T(n=380)$ & WMH $(n=348)$ \\
\hline Age, y & $70.48(8.04)$ & $70.41(8.03)$ & $70.39(8.07)$ & $70.28(8.04)$ \\
\hline Female, n (\%) & $222(56.06)$ & $218(56.19)$ & $215(56.58)$ & $191(54.89)$ \\
\hline Education, y & $11.01(4.80)$ & $11.14(4.83)$ & $11.16(4.81)$ & $11.23(4.76)$ \\
\hline APOE $\varepsilon 4$ positivity, $\mathrm{n}(\%)$ & $78(19.70)$ & $76(19.59)$ & $73(19.21)$ & $66(18.97)$ \\
\hline CN, n (\%) & $284(71.72)$ & $281(72.42)$ & $275(72.37)$ & $256(73.56)$ \\
\hline \multicolumn{5}{|l|}{ Serum albumin level } \\
\hline Overall serum albumin, g/dL & $4.47(0.24)$ & $4.46(0.24)$ & $4.46(0.24)$ & $4.47(0.24)$ \\
\hline \multicolumn{5}{|l|}{ Categorized serum albumin, n (\%) } \\
\hline Low: $3.6-4.3 \mathrm{~g} / \mathrm{dL}$ & $117(29.55)$ & $117(30.15)$ & $115(30.26)$ & $99(28.45)$ \\
\hline Middle: $4.4-4.5 \mathrm{~g} / \mathrm{dL}$ & $132(33.33)$ & $127(32.73)$ & $125(29.89)$ & $116(33.33)$ \\
\hline High: $4.6-5.3 \mathrm{~g} / \mathrm{dL}$ & $147(37.12)$ & $144(37.11)$ & $140(36.84)$ & $133(38.22)$ \\
\hline \multicolumn{5}{|l|}{ Alcohol use, n (\%) } \\
\hline Never & $211(53.28)$ & 207 (53.49) & $204(53.83)$ & $185(53.31)$ \\
\hline Former & $52(13.13)$ & $50(12.92)$ & $49(12.93)$ & $45(12.97)$ \\
\hline Drinker & $132(33.33)$ & $130(33.59)$ & $126(33.25)$ & $117(33.72)$ \\
\hline \multicolumn{5}{|l|}{ Medication use within 4 wk, $n$ (\%) } \\
\hline No & $84(21.21)$ & $84(21.71)$ & $84(22.16)$ & $73(21.04)$ \\
\hline Yes & $311(78.54)$ & $303(78.29)$ & $295(77.84)$ & $274(78.96)$ \\
\hline \multicolumn{5}{|c|}{ Decrease in food intake over the past $3 \mathrm{mo}, \mathrm{n}(\%)$} \\
\hline No & $327(83.00)$ & $369(95.60)$ & $362(95.51)$ & $330(95.38)$ \\
\hline Yes & $67(17.00)$ & $17(4.40)$ & $17(4.49)$ & $16(4.62)$ \\
\hline \multicolumn{5}{|l|}{ Medical condition, $\mathrm{n}(\%)$} \\
\hline Liver disease & $69(17.42)$ & $69(17.78)$ & $68(17.89)$ & $62(17.82)$ \\
\hline Kidney disease & $16(4.04)$ & $16(4.12)$ & $15(3.95)$ & $16(4.60)$ \\
\hline Diabetes mellitus & $66(16.67)$ & $66(17.01)$ & $62(16.32)$ & $59(16.95)$ \\
\hline Hyperlipidemia & $136(34.34)$ & 135 (34.79) & $132(34.74)$ & $126(36.21)$ \\
\hline \multicolumn{5}{|l|}{ Cerebral $A \beta$ deposition } \\
\hline Global $A \beta$ retention, SUVR & & $1.21(0.26)$ & & \\
\hline$A \beta$ positivity, $n(\%)$ & & $68(17.17)$ & & \\
\hline \multicolumn{5}{|l|}{ Neurodegeneration } \\
\hline AD-CM, SUVR & & $1.40(0.12)$ & & \\
\hline $\mathrm{AD}-\mathrm{CT}, \mathrm{mm}$ & & & $2.82(0.20)$ & \\
\hline WMH volume, $\mathrm{cm}^{3}$ & & & & $5.95(5.43)$ \\
\hline
\end{tabular}

Abbreviations: $A \beta=\beta$-amyloid protein; $A D-C M=$ Alzheimer disease-signature cerebral glucose metabolism; $A D-C T$ = Alzheimer disease-signature cortical thickness; $\mathrm{CN}$ = cognitively normal; SUVR = standardized uptake value ratio; $\mathrm{WMH}=$ white matter hyperintensities.

a Unless otherwise indicated, data are expressed as mean (SD).

psychiatrists and neuropsychologists according to the KBASE assessment protocol, ${ }^{18}$ which incorporates the Korean version of the Consortium to Establish a Registry for Alzheimer's Disease. ${ }^{21,22}$ Medication use within 4 weeks and alcohol intake status (never/former/drinker) were evaluated by nurse interviews and by a review of medical 
Table 2 Relationships between serum albumin and neuroimaging biomarkers

\begin{tabular}{|c|c|c|c|}
\hline Serum albumin & OR & $95 \% \mathrm{Cl}$ & $p$ Value \\
\hline \multicolumn{4}{|c|}{ Dependent variable: $A \beta$ positivity $(n=388)$} \\
\hline Model $1^{a}$ & 0.13 & $0.04-0.39$ & $<0.001$ \\
\hline Model $2^{b}$ & 0.16 & $0.05-0.52$ & 0.002 \\
\hline \multirow[t]{2}{*}{ Model $3^{c}$} & 0.17 & $0.05-0.58$ & 0.004 \\
\hline & B & $95 \% \mathrm{Cl}$ & $p$ Value \\
\hline \multicolumn{4}{|c|}{ Dependent variable: global $A \beta$ retention $(n=388)$} \\
\hline Model $1^{a}$ & -0.14 & -0.21 to -0.06 & $<0.001$ \\
\hline Model $2^{b}$ & -0.11 & -0.18 to -0.04 & 0.002 \\
\hline Model $3^{c}$ & -0.09 & -0.16 to -0.03 & 0.008 \\
\hline \multicolumn{4}{|c|}{ Dependent variable: AD-CM $(n=388)$} \\
\hline Model $1^{a}$ & 0.01 & -0.05 to 0.06 & 0.816 \\
\hline Model $2^{b}$ & $-<0.01$ & -0.06 to 0.05 & 0.885 \\
\hline Model $3^{c}$ & $<0.01$ & -0.05 to 0.06 & 0.883 \\
\hline \multicolumn{4}{|c|}{ Dependent variable: AD-CT $(n=380)$} \\
\hline Model $1^{a}$ & 0.07 & -0.01 to 0.16 & 0.092 \\
\hline Model $2^{b}$ & 0.03 & -0.05 to 0.10 & 0.457 \\
\hline Model $3^{c}$ & 0.02 & -0.06 to 0.09 & 0.641 \\
\hline \multicolumn{4}{|c|}{ Dependent variable: WMH volume $(n=348)$} \\
\hline Model $1^{a}$ & 0.38 & -2.03 to 2.79 & 0.758 \\
\hline Model $2^{b}$ & 0.79 & -1.58 to 3.16 & 0.513 \\
\hline Model $3^{c}$ & 0.68 & -1.74 to 3.10 & 0.581 \\
\hline \multicolumn{4}{|c|}{$\begin{array}{l}\text { Abbreviations: } \mathrm{A} \beta=\beta \text {-amyloid protein; } \mathrm{AD}-\mathrm{CM}=\text { Alzheimer disease-signature cerebral glucose metabolism; } \mathrm{AD}-\mathrm{CT}=\text { Alzheimer disease-signature cortical } \\
\text { thickness; } \mathrm{Cl}=\text { confidence interval; } \mathrm{OR}=\text { odds ratio; } \mathrm{WMH}=\text { white matter hyperintensities. } \\
\text { Global } \mathrm{A} \beta \text { retention was used after natural log-transformation to achieve a normal distribution. } \\
\text { a Not adjusted. } \\
\text { b Adjusted for age, sex, and } A P O E \varepsilon 4 \text {. } \\
\text { 'A Adjusted for age, sex, } A P O E \& 4 \text {, education, clinical diagnosis, medication use, alcohol use, annual income, diabetes mellitus, hyperlipidemia, liver disease, and } \\
\text { kidney disease. }\end{array}$} \\
\hline
\end{tabular}

records. Participants were divided into 3 groups according to annual income: below the minimum cost of living (MCL), above the MCL but below twice the MCL, and twice the MCL or more (law.go.kr). The MCL was determined according to the administrative rules published by the Ministry of Health and Welfare, Republic of Korea, in November 2012. The MCL was 572,168 Korea Won for single-person households and added 286,840 Korea Won for each additional housemate. The presence of comorbid diabetes mellitus, dyslipidemia, liver disease, and kidney disease was assessed from data collected by trained nurses during systematic interviews of participants and their reliable informants. Information about nutritional state, including the change in food intake over the past 3 months due to loss of appetite, digestive problems, or chewing or swallowing difficulties, was systematically obtained by using the Mini Nutritional Assessment tool. ${ }^{23}$ To acquire accurate information, reliable informants were interviewed and medical records were reviewed.

\section{Laboratory tests of blood samples}

Blood samples were obtained by venipuncture after an overnight fast. The concentration of albumin was determined by bromocresol green dye binding assay (ADVIA 1800; Siemens, Washington, DC). The normal range for albumin level is 3.5 to $5.5 \mathrm{~g} / \mathrm{dL}$. Participants were categorized on the basis of serum albumin level using tertiles referring to previous studies ${ }^{24,25}$ as follows: low albumin, $<4.4$ $\mathrm{g} / \mathrm{dL}$; middle albumin, 4.4 to $4.5 \mathrm{~g} / \mathrm{dL}$; and high albumin, $>4.5 \mathrm{~g} / \mathrm{dL}$ (used as a reference category). In addition, genomic DNA was extracted from whole blood, and $A P O E$ genotyping was performed as described previously. ${ }^{26} \mathrm{APOE}$ $\varepsilon 4$ positivity was defined as the presence of at least $1 \& 4$ allele. 

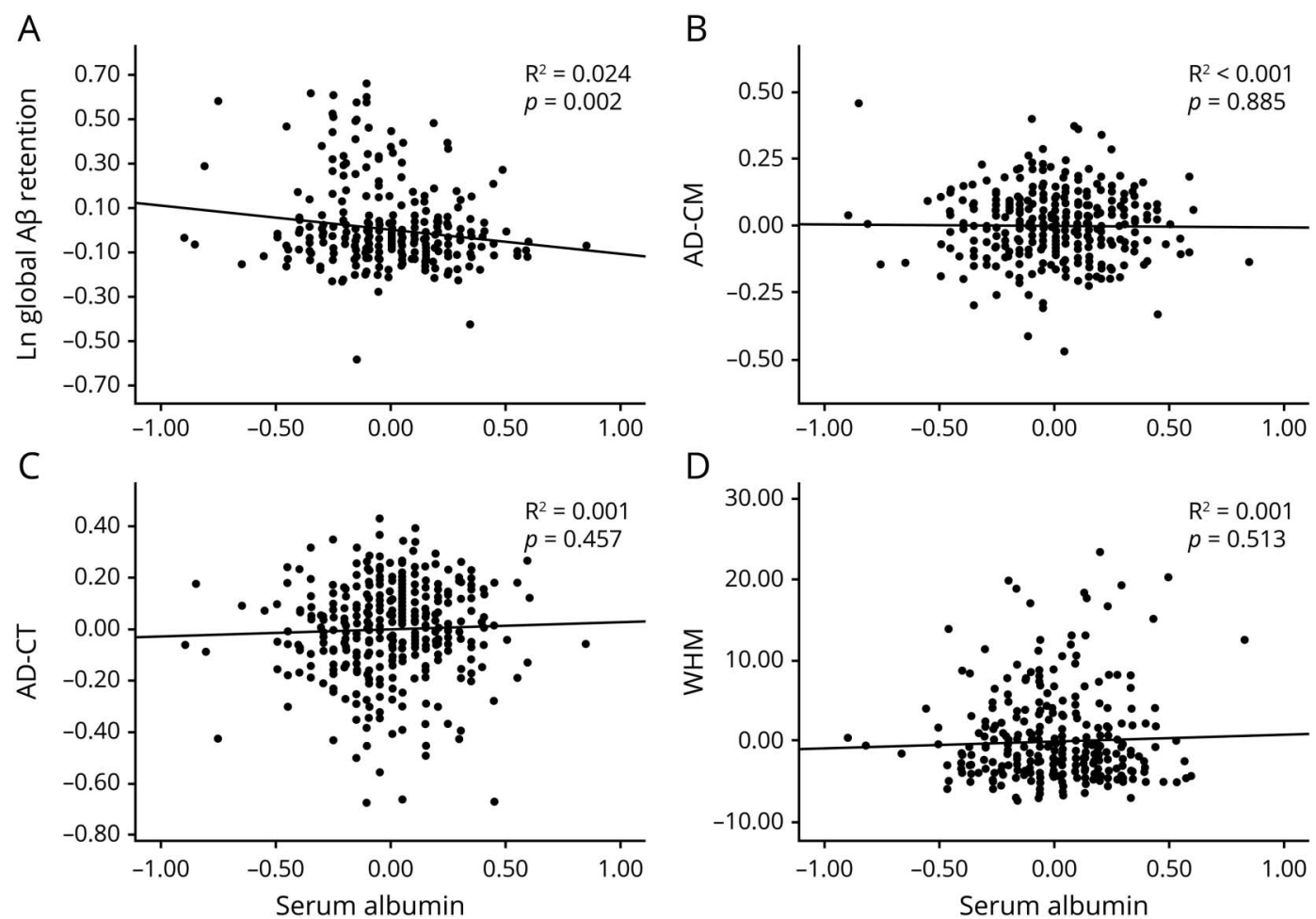

Multiple linear regression analysis was performed for (A) global A $\beta$ retention, (B) AD-CM, (C) AD-CT, and (D) WHM after adjustment for age, sex, and APOE \&4. Global $A \beta$ retention was used after natural log transformation to achieve a normal distribution. $A \beta=$ beta-amyloid protein; $A D-C M=A l z h e i m e r$ disease-signature cerebral glucose metabolism; AD-CT = Alzheimer disease-signature cortical thickness; $\mathrm{WMH}=$ white matter hyperintensities .

\section{Measurement of cerebral $A \beta$ deposition}

All participants underwent simultaneous 3D $\left[{ }^{11} \mathrm{C}\right]$ Pittsburgh compound $\mathrm{B}(\mathrm{PiB})$-PET and 3D T1-weighted MRI scan with a 3.0T Biograph mMR (PET-MR) scanner (Siemens) according to the manufacturer's guidelines. Details of the PiB-PET imaging acquisition and preprocessing were described previously. ${ }^{27}$ An automatic anatomic labeling algorithm and a region-combining method $^{28}$ were applied to determine regions of interest (ROIs) to characterize the $\mathrm{PiB}$ retention levels in the frontal, lateral parietal, posterior cingulate-precuneus, and lateral temporal regions. The standardized uptake value ratio (SUVR) value for each ROI was calculated by dividing the mean value for all voxels within each ROI by the mean cerebellar uptake value in the same image. A global cortical ROI consisting of the 4 ROIs was also defined, and a global $A \beta$ retention value was generated by dividing the mean value for all voxels of the global cortical ROI by the mean cerebellar uptake value in the same image. ${ }^{28,29}$ Given the characteristic skewed distribution of cerebral $A \beta$ deposition values, global $A \beta$ retention data were used after natural logtransformation and removal of extreme outliers to achieve a normal distribution with reference to previous reports. ${ }^{30,31}$ Amyloid positivity was also used as an outcome variable. Each participant was classified as A $\beta$-positive $(\mathrm{A} \beta+)$ if the SUVR value was $>1.4$ in at least 1 of the 4 ROIs or as $A \beta$-negative $(A \beta-)$ if the SUVR values were $\leq 1.4$ for all 4 ROIs. ${ }^{28,32}$

\section{Measurement of AD-signature neurodegeneration}

All participants underwent ${ }^{18} \mathrm{~F}$-fluorodeoxyglucose (FDG)PET imaging with the abovementioned PET-MR machine. Details of the FDG-PET image acquisition and preprocessing were described previously. ${ }^{27} \mathrm{AD}$-signature FDG ROIs such as the angular gyri, posterior cingulate cortex, and inferior temporal gyri, which are sensitive to the changes associated with $\mathrm{AD},{ }^{32}$ were determined. $\mathrm{AD}$-signature cerebral glucose metabolism $(\mathrm{AD}-\mathrm{CM})$ was defined as the voxel-weighted mean SUVR extracted from the AD-signature FDG ROIs. Details of MRI acquisition and preprocessing were described previously. ${ }^{27} \mathrm{AD}$-signature cortical thickness $(\mathrm{AD}-\mathrm{CT})$ was defined as the mean cortical thickness values obtained from $\mathrm{AD}$-signature regions, including the entorhinal, inferior temporal, middle temporal, and fusiform gyrus, as described previously. $^{32}$

\section{Measurement of WMH}

All participants underwent MRI scans with fluid-attenuated inversion recovery (FLAIR) using the abovementioned 3.0T PET-MR scanner. We followed the validated automatic procedure reported previously. ${ }^{33}$ Briefly, the procedure 
Table 3 Relationships between stratified serum albumin and neuroimaging biomarkers

\begin{tabular}{|c|c|c|c|c|c|}
\hline & \multicolumn{5}{|c|}{ Stratified serum albumin } \\
\hline & \multicolumn{2}{|l|}{ Low $(<4.4 \mathrm{~g} / \mathrm{dL})$} & \multicolumn{2}{|l|}{ Middle (4.4-4.5 g/dL) } & \multirow[t]{2}{*}{ High (>4.5 g/dL) } \\
\hline & OR $(95 \% \mathrm{CI})$ & $p$ Value & OR $(95 \% \mathrm{Cl})$ & $p$ Value & \\
\hline \multicolumn{6}{|c|}{$A \beta$ positivity $(n=388)$} \\
\hline Model $1^{a}$ & $3.96(2.01-7.81)$ & $<0.001$ & $1.55(0.74-3.26)$ & 0.250 & Reference \\
\hline Model $2^{b}$ & $3.40(1.67-6.92)$ & 0.001 & $1.74(0.80-3.77)$ & 0.162 & Reference \\
\hline \multirow[t]{2}{*}{ Model $3^{c}$} & $3.08(1.47-6.46)$ & 0.003 & $1.77(0.79-3.99)$ & 0.168 & Reference \\
\hline & B $(95 \% \mathrm{Cl})$ & $p$ Value & B $(95 \% \mathrm{Cl})$ & $p$ Value & \\
\hline \multicolumn{6}{|c|}{ Global $A \beta$ retention $(n=388)$} \\
\hline Model $1^{a}$ & 0.09 (0.05 to 0.13$)$ & $<0.001$ & $<0.01(-0.03$ to 0.05$)$ & 0.719 & Reference \\
\hline Model $2^{b}$ & 0.07 (0.03 to 0.11$)$ & $<0.001$ & $0.01(-0.03$ to 0.05$)$ & 0.623 & Reference \\
\hline Model $3^{c}$ & 0.06 (0.02 to 0.10$)$ & 0.006 & $<0.01(-0.03$ to 0.05$)$ & 0.751 & Reference \\
\hline \multicolumn{6}{|c|}{$A D-C M(n=388)$} \\
\hline Model $1^{a}$ & $-0.01(-0.05$ to 0.02$)$ & 0.372 & $0.01(-0.03$ to 0.04$)$ & 0.735 & Reference \\
\hline Model $2^{b}$ & $-0.01(-0.04$ to 0.02$)$ & 0.659 & $0.01(-0.02$ to 0.04$)$ & 0.669 & Reference \\
\hline Model $3^{c}$ & $-0.01(-0.04$ to 0.02$)$ & 0.592 & $0.01(-0.02$ to 0.04$)$ & 0.712 & Reference \\
\hline \multicolumn{6}{|c|}{$A D-C T(n=380)$} \\
\hline Model $1^{a}$ & $-0.07(-0.12$ to -0.02$)$ & 0.009 & $0.01(-0.04$ to 0.06$)$ & 0.680 & Reference \\
\hline Model $2^{b}$ & $-0.04(-0.08$ to 0.01$)$ & 0.124 & $0.01(-0.03$ to 0.05$)$ & 0.625 & Reference \\
\hline Model $3^{c}$ & $-0.03(-0.07$ to 0.02$)$ & 0.246 & $0.01(-0.03$ to 0.05$)$ & 0.616 & Reference \\
\hline \multicolumn{6}{|c|}{ WMH $(n=340)$} \\
\hline Model $1^{a}$ & $0.29(-1.13$ to 1.71$)$ & 0.687 & $-0.16(-1.52$ to 1.21$)$ & 0.821 & Reference \\
\hline Model $2^{b}$ & $-0.04(-1.45$ to 1.37$)$ & 0.959 & $-0.35(-1.69$ to 0.99$)$ & 0.609 & Reference \\
\hline Model $3^{c}$ & $0.04(-1.40$ to 1.48$)$ & 0.956 & $-0.26(-1.62$ to 1.10$)$ & 0.707 & Reference \\
\hline
\end{tabular}

Abbreviations: $A \beta=\beta$-amyloid protein; $A D-C M=$ Alzheimer disease-signature cerebral glucose metabolism; $A D-C T$ = Alzheimer disease-signature cortical thickness; $\mathrm{Cl}=$ confidence interval; $\mathrm{OR}=$ odds ratio; $\mathrm{WMH}=$ white matter hyperintensities.

Global $A \beta$ retention was used after natural log-transformation to achieve a normal distribution.

${ }^{\text {a }}$ Not adjusted.

${ }^{\mathrm{b}}$ Adjusted for age, sex, and $A P O E \varepsilon 4$.

'Adjusted for age, sex, $A P O E \& 4$, education, clinical diagnosis, medication use, alcohol use, annual income, diabetes mellitus, hyperlipidemia, liver disease, and kidney disease.

consisted of 11 steps: spatial coregistration of T1 and FLAIR images; fusion of T1 and FLAIR images; segmentation of $\mathrm{T} 1$; attainment of transformation parameters; deformation and obtainment of the white matter mask; obtainment of FLAIR within the white matter mask; intensity normalization of the masked FLAIR; nomination of candidate WMH with a designated threshold; creation of a junction map; and elimination of the junction. There were 2 modifications in the current processing procedure compared to the original study: (1) an optimal threshold of 70 was applied because it was more suitable for our data compared to the threshold of 65 used in the original study; and, (2) given that individuals with acute cerebral infarcts were not enrolled in our sample, we did not use diffusion-weighted imaging in the current automated procedure. With the use of the final WMH candidate image, the $\mathrm{WMH}$ volume was extracted in the native space in each subject.

\section{Statistical analysis}

Multiple linear regression analysis with serum albumin (continuous variable) as the independent variable and $\mathrm{AD}$ neuroimaging parameters $(\mathrm{A} \beta$ deposition, $\mathrm{AD}-\mathrm{CM}, \mathrm{AD}-\mathrm{CT}$, and $\mathrm{WMH}$ ) as the dependent variables was performed. Multiple logistic regression analysis with serum albumin (continuous variables or categorical variables, i.e., low albumin, middle albumin, and high albumin) as the independent variable and $\mathrm{A} \beta$ positivity as the dependent variable was also conducted. Three models were tested for stepwise control of 

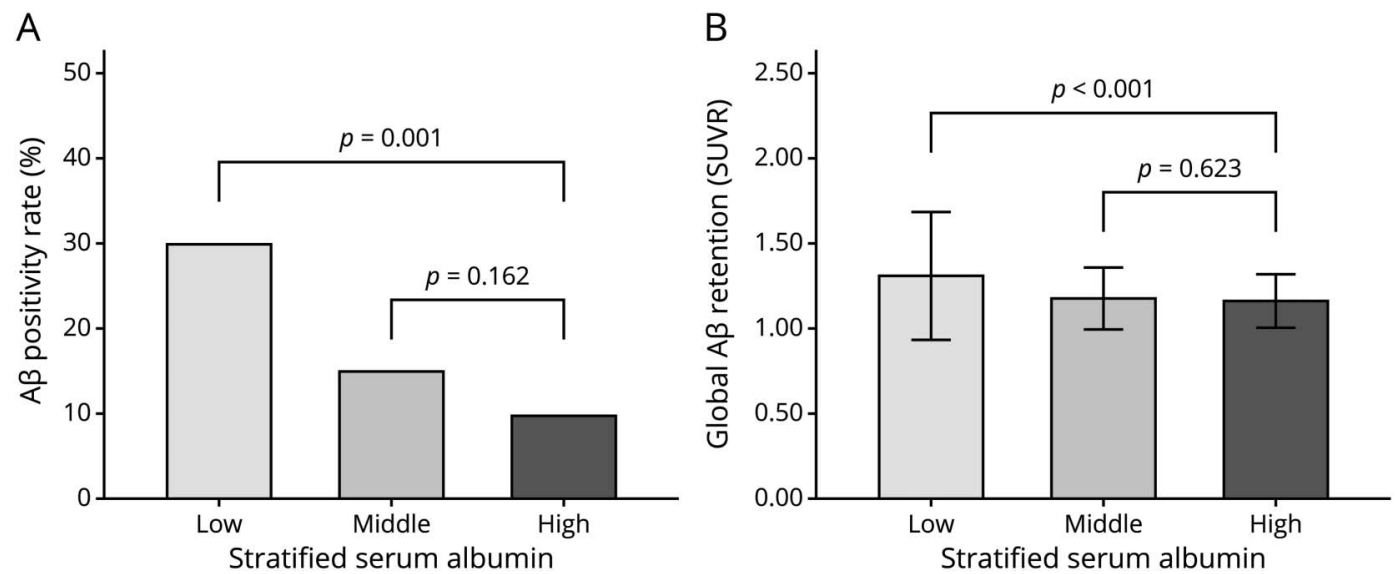

Multiple regression analyses were performed for (A) $\beta$-amyloid ( $A \beta$ ) positivity and (B) global $A \beta$ retention after adjustment for age, sex, and $A P O E \varepsilon 4$. Error bars represent standard deviation.

potential confounders that could affect the relationships between albumin and $\mathrm{AD}$ biomarkers. The first model did not include any covariates. The second model included age ( $<70$ vs $\geq 70$ years), sex (female vs male), and APOE 84 positivity $(+/-)$ as covariates. The third model included all potential covariates: age, sex, APOE $\varepsilon 4$, education, clinical diagnosis ( $\mathrm{CN}$ vs $\mathrm{MCI}$ ), medication use within 4 weeks $(+/-)$, alcohol use (no/former/drinker), annual income, diabetes mellitus $(+/-)$, hyperlipidemia $(+/-)$, liver disease $(+/-)$, and kidney disease $(+/-)$, which have been considered possible confounders in previous studies. ${ }^{25,34-38}$ In the analysis, high albumin was used as a reference (i.e., high albumin vs middle albumin, or high albumin vs low albumin). As sensitivity analyses, the same analyses were performed for the subjects with no decrease in food intake over the past 3 months due to loss of appetite, digestive problems, or chewing or swallowing difficulties to eliminate any influence of physical or mental conditions that can potentially relate to both serum albumin level and brain status. Statistical analyses were performed with IBM SPSS Statistics 24 (IBM Corp, Armonk, NY). In all analyses, values of $p<0.05$ were taken to indicate statistical significance.

\section{Data availability}

The data for this analysis are owned by the KBASE research group. Requests for data access can be submitted to the administrative coordinator of the group by e-mail (kbasecohort@gmail.com).

\section{Results}

\section{Participant characteristics}

The demographic and clinical characteristics of the participants are presented in table 1. All participants had serum albumin levels within normal range. Among them, 117 were categorized as having low albumin, 132 as having middle albumin, and 147 as having high albumin group.

\section{Association of serum albumin with cerebral amyloid deposition}

Serum albumin level (as a continuous variable) was significantly associated with global $A \beta$ retention (table 2 and figure $1 A)$ and $A \beta$ positivity after controlling for the covariates (table 2). Furthermore, the low albumin category was significantly associated with higher $A \beta$ positivity compared to the high albumin category after controlling for the covariates, while the middle albumin category showed no relation to $A \beta$ positivity (table 3 and figure 2).

\section{Association of serum albumin with AD- signature neurodegeneration and $\mathrm{WMH}$}

Serum albumin level (as a continuous variable) was not related to $\mathrm{AD}-\mathrm{CM}, \mathrm{AD}-\mathrm{CT}$, or $\mathrm{WMH}$ (table 2 and figure 1 , $\mathrm{B}-\mathrm{D})$. Moreover, no differences were observed in $\mathrm{AD}-\mathrm{CM}$, $\mathrm{AD}-\mathrm{CT}$, or $\mathrm{WMH}$ between the serum albumin categories (table 3).

\section{Sensitivity analyses}

The same analyses for the individuals with no decrease in food intake over the past 3 months produced similar results for $\mathrm{A} \beta$ deposition (or $\mathrm{A} \beta$ positivity), $\mathrm{AD}-\mathrm{CM}, \mathrm{AD}-\mathrm{CT}$, and $\mathrm{WMH}$ (tables 4 and 5 and figure 3 ).

\section{Discussion}

The results of the present study showed that low serum albumin was associated with an increased cerebral $A \beta$ positivity rate compared to high serum albumin in older adults without dementia. The findings presented here were consistent with results of previous human studies on the relationships between serum albumin level and cognitive decline or $\mathrm{AD}$ dementia. 
Table 4 Relationships between serum albumin and neuroimaging biomarkers in individuals with no recent decrease in food intake

\begin{tabular}{|c|c|c|c|}
\hline Serum albumin & OR & $95 \% \mathrm{Cl}$ & $p$ Value \\
\hline \multicolumn{4}{|c|}{ Dependent variable: $A \beta$ positivity $(n=320)$} \\
\hline Model $1^{a}$ & 0.10 & 0.03 to 0.35 & $<0.001$ \\
\hline Model $2^{\mathrm{b}}$ & 0.15 & 0.04 to 0.57 & 0.005 \\
\hline \multirow[t]{2}{*}{ Model $3^{c}$} & 0.18 & 0.04 to 0.70 & 0.014 \\
\hline & B & $95 \% \mathrm{Cl}$ & $p$ Value \\
\hline \multicolumn{4}{|c|}{ Dependent variable: global $A \beta$ retention $(n=320)$} \\
\hline Model $1^{a}$ & -0.15 & -0.24 to -0.07 & $<0.001$ \\
\hline Model $2^{\mathbf{b}}$ & -0.11 & -0.19 to -0.03 & 0.006 \\
\hline Model $3^{c}$ & -0.10 & -0.18 to -0.02 & 0.014 \\
\hline \multicolumn{4}{|c|}{ Dependent variable: AD-CM $(n=320)$} \\
\hline Model $1^{a}$ & 0.01 & -0.05 to 0.07 & 0.792 \\
\hline Model $2^{b}$ & -0.01 & -0.07 to 0.05 & 0.768 \\
\hline Model $3^{c}$ & $-<0.01$ & -0.06 to 0.06 & 0.903 \\
\hline \multicolumn{4}{|c|}{ Dependent variable: AD-CT $(n=314)$} \\
\hline Model $1^{a}$ & 0.09 & $-<0.01$ to 0.18 & 0.060 \\
\hline Model $2^{b}$ & 0.03 & -0.06 to 0.11 & 0.555 \\
\hline Model $3^{c}$ & 0.01 & -0.07 to 0.09 & 0.836 \\
\hline \multicolumn{4}{|c|}{ Dependent variable: WMH volume $(n=286)$} \\
\hline Model $1^{a}$ & 0.46 & -2.31 to 3.23 & 0.743 \\
\hline Model $2^{b}$ & 1.01 & -1.76 to 3.78 & 0.474 \\
\hline Model $3^{c}$ & 1.08 & -1.78 to 3.94 & 0.460 \\
\hline
\end{tabular}

Abbreviations: $A \beta=\beta$-amyloid protein; $A D-C M=$ Alzheimer disease-signature cerebral glucose metabolism; $A D-C T=A l z h e i m e r$ disease-signature cortical thickness; $\mathrm{Cl}=$ confidence interval; $\mathrm{OR}=$ odds ratio; $\mathrm{WMH}=$ white matter hyperintensities.

Global $A \beta$ retention was used after natural log-transformation to achieve a normal distribution.

a Not adjusted.

${ }^{\mathrm{b}}$ Adjusted for age, sex, and $A P O E \& 4$.

' Adjusted for age, sex, $A P O E$ \&4, education, clinical diagnosis, medication use, alcohol use, annual income, diabetes mellitus, hyperlipidemia, liver disease, and kidney disease.

One population-based longitudinal study showed that low albumin within the normal range was an independent risk marker for cognitive decline in community-living older adults. ${ }^{34}$ Previous clinical studies in hospital inpatients also showed that low serum albumin was associated with cognitive impairment ${ }^{11,39}$ and late-onset $\mathrm{AD}$ dementia compared with controls. ${ }^{14,40,41}$

The inverse association of serum albumin with $A \beta$ deposition observed in the present study supports the so-called sink hypothesis, ${ }^{42,43}$ which suggests that $A \beta$ shifts from the brain into the blood plasma, forming a decrease in the $A \beta$ concentration gradient between the brain and blood plasma. In this process, serum albumin binds most of the $A \beta$ in the blood plasma and, in turn, lowers the blood plasma $A \beta$ concentration. Therefore, serum albumin plays an important role in the
$A \beta$ shift from the brain to the blood plasma for balancing the dynamic equilibrium of $A \beta$ between the brain and blood plasma. Low serum albumin results in less binding to $A \beta$ in blood, which increases blood plasma $A \beta$ concentration, resulting in increased $A \beta$ deposition in the brain by blocking the $A \beta$ shift due to its lower concentration difference. An alternative hypothesis suggests that serum albumin is an endogenous inhibitor of $A \beta$ fibril formation. ${ }^{7,10}$ Serum albumin may act on $A \beta$ in 3 ways-monomer stabilizer, dissociation catalyst, or monomer competitor-and thus may prevent fibril formation. However, the possibility of reverse causality should also be considered. Poor nutrition in patients with dementia can reduce serum albumin level. This may explain the relationships between low serum albumin and $\mathrm{AD}$ dementia reported previously. ${ }^{14,15}$ Because all of our subjects were without dementia, however, reverse causality could not 
Table 5 Relationships between stratified serum albumin and neuroimaging biomarkers in individuals with no recent decrease in food intake

\begin{tabular}{|c|c|c|c|c|c|}
\hline & \multicolumn{5}{|c|}{ Stratified serum albumin } \\
\hline & \multicolumn{2}{|l|}{ Low $(<4.4 \mathrm{~g} / \mathrm{dL})$} & \multicolumn{2}{|l|}{ Middle (4.4-4.5 g/dL) } & \multirow[t]{2}{*}{ High $(>4.5 \mathrm{~g} / \mathrm{dL})$} \\
\hline & OR $(95 \% \mathrm{Cl})$ & $p$ Value & OR $(95 \% \mathrm{Cl})$ & $p$ Value & \\
\hline \multicolumn{6}{|c|}{$A \beta$ positivity $(n=320)$} \\
\hline Model $1^{a}$ & $4.76(2.22-10.21)$ & $<0.001$ & $1.86(0.82-4.21)$ & 0.135 & Reference \\
\hline Model $2^{b}$ & $3.80(1.72-8.40)$ & 0.001 & $1.97(0.85-4.57)$ & 0.116 & Reference \\
\hline \multirow[t]{2}{*}{ Model $3^{c}$} & $3.30(1.43-7.61)$ & 0.005 & $2.19(0.89-5.39)$ & 0.087 & Reference \\
\hline & B $(95 \% \mathrm{Cl})$ & $p$ Value & B $(95 \% \mathrm{Cl})$ & $p$ Value & \\
\hline \multicolumn{6}{|c|}{ Global $A \beta$ retention $(n=320)$} \\
\hline Model $1^{a}$ & 0.10 (0.06 to 0.15$)$ & $<0.001$ & $0.01(-0.03$ to 0.06$)$ & 0.593 & Reference \\
\hline Model $2^{b}$ & 0.08 (0.03 to 0.13$)$ & 0.001 & $0.01(-0.03$ to 0.05$)$ & 0.647 & Reference \\
\hline Model $3^{c}$ & 0.06 (0.02 to 0.11$)$ & 0.007 & $0.01(-0.03$ to 0.05$)$ & 0.639 & Reference \\
\hline \multicolumn{6}{|c|}{$A D-C M(n=320)$} \\
\hline Model $1^{a}$ & $-0.02(-0.05$ to 0.02$)$ & 0.287 & $-0.01(-0.04$ to 0.03$)$ & 0.713 & Reference \\
\hline Model $2^{b}$ & $-0.01(-0.04$ to 0.03$)$ & 0.628 & $-<0.01$ (-0.04 to 0.03$)$ & 0.813 & Reference \\
\hline Model $3^{c}$ & $-0.01(-0.05$ to 0.03$)$ & 0.590 & $-<0.01(-0.04$ to 0.03$)$ & 0.816 & Reference \\
\hline \multicolumn{6}{|c|}{$A D-C T(n=314)$} \\
\hline Model $1^{a}$ & $-0.08(-0.13$ to -0.02$)$ & 0.005 & $0.01(-0.04$ to 0.06$)$ & 0.774 & Reference \\
\hline Model $2^{b}$ & $-0.04(-0.09$ to 0.01$)$ & 0.111 & $0.01(-0.03$ to 0.06$)$ & 0.641 & Reference \\
\hline Model $3^{c}$ & $-0.03(-0.07$ to 0.02$)$ & 0.297 & $0.02(-0.03$ to 0.06$)$ & 0.499 & Reference \\
\hline \multicolumn{6}{|c|}{ WMH (n = 286) } \\
\hline Model $1^{\text {a }}$ & 0.39 (-1.23 to 2.00$)$ & 0.639 & $-0.17(-1.68$ to 1.35$)$ & 0.828 & Reference \\
\hline Model $2^{b}$ & $0.02(-1.60$ to 1.64$)$ & 0.982 & $-0.38(-1.88$ to 1.11$)$ & 0.613 & Reference \\
\hline Model $3^{c}$ & $-0.03(-1.71$ to 1.64$)$ & 0.969 & $-0.41(-1.95$ to 1.13$)$ & 0.598 & Reference \\
\hline
\end{tabular}

Abbreviations: $A \beta=\beta$-amyloid protein; $A D-C M=$ Alzheimer disease-signature cerebral glucose metabolism; $A D-C T$ = Alzheimer disease-signature cortical thickness; $\mathrm{Cl}=$ confidence interval; $\mathrm{OR}=$ odds ratio; $\mathrm{WMH}=$ white matter hyperintensities.

Global $A \beta$ retention was used after natural log-transformation to achieve a normal distribution.

a Not adjusted.

${ }^{\mathrm{b}}$ Adjusted for age, sex, and $A P O E \varepsilon 4$.

'Adjusted for age, sex, $A P O E \& 4$, education, clinical diagnosis, medication use, alcohol use, annual income, diabetes mellitus, hyperlipidemia, liver disease, and kidney disease.

explain our observation of the relationship between albumin and $\mathrm{A} \beta$ deposition.

In terms of $A \beta$ positivity risk, the odds ratio for low albumin category was 3.40 (95\% confidence interval $1.67-6.92, p=$ $0.001)$ compared with the high albumin category. This means that, even within the normal range of serum albumin, individuals with serum albumin $<4.4 \mathrm{~g} / \mathrm{dL}$ have an $\approx 3$ times higher risk of pathologic $A \beta$ deposition. This finding also indicates that nutritional interventions such as high dietary protein or albumin replacement may be helpful for those with low serum albumin in terms of $\mathrm{AD}$ prevention or treatment. Recently, the Alzheimer's Management by Albumin Replacement (AMBAR) trial was conducted to demonstrate the clinical efficacy of therapeutic albumin replacement with plasma exchange as a new treatment of AD. ${ }^{44,45}$ Our result may provide an additional rationale for this kind of trial.

Unlike the relationship with $A \beta$, serum albumin was not related to either $\mathrm{AD}$-signature neurodegeneration or $\mathrm{WMH}$. While the relationships between low serum albumin and $\mathrm{AD}$ dementia have been reported as mentioned above, very little information is available on the relationships of serum albumin with degenerative changes in the brain. ${ }^{14,15}$ The lack of association between serum albumin and $\mathrm{AD}-\mathrm{CM}$ or $\mathrm{AD}-\mathrm{CT}$ in the present study indicated that serum albumin does not directly affect metabolism or structural changes in 
Figure 3 Partial correlation plot for the relationship of serum albumin with global $A \beta$ retention in individuals with no recent decrease in food intake

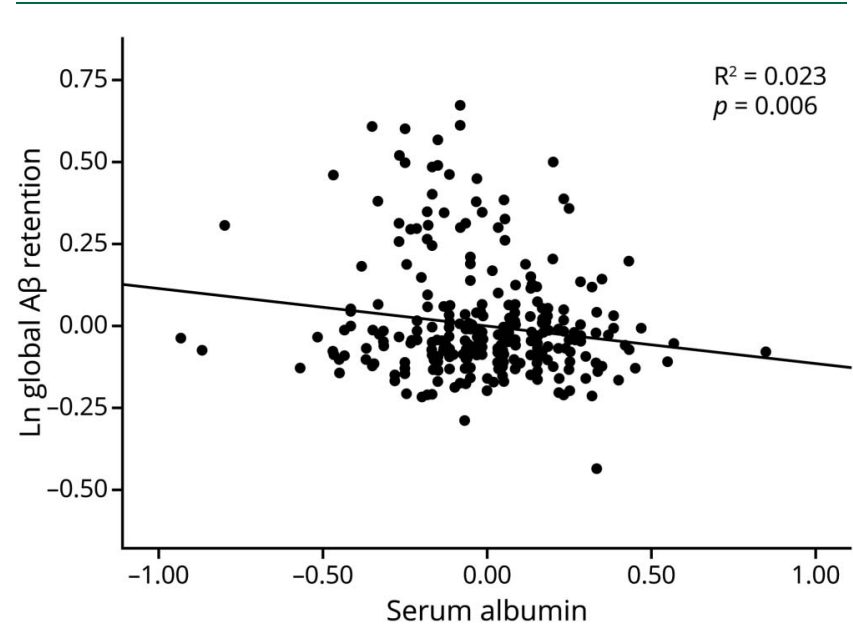

Multiple linear regression analysis was performed after adjustment for age, sex, and $A P O E \& 4$. Global $\beta$-amyloid $(A \beta)$ retention was used after natural logtransformation to achieve a normal distribution.

$\mathrm{AD}$-related brain regions in older adults. We did not find any relationship between serum albumin and WMH. In addition, some human studies have reported an inverse association between serum albumin and cerebrovascular disease. ${ }^{16,17}$ The discrepancy may be related to the difference in range of serum albumin concentrations. While our subjects had serum albumin levels within the normal range, the previous studies mentioned above included subjects with serum albumin levels below the normal range (total levels $3.0-5.7 \mathrm{~g} /$ $\mathrm{dL}$, low levels $3.0-3.9 \mathrm{~g} / \mathrm{dL}$ in 1 study $^{16}$; total levels $2.7-5.5$ $\mathrm{g} / \mathrm{dL}$, low levels $2.7-4.2 \mathrm{~g} / \mathrm{dL}$ in the other ${ }^{17}$; and total levels 3.6-5.3 g/dL, low levels 3.6-4.3 g/dL in our study). Therefore, serum albumin level below the normal range may increase cerebrovascular injury, as shown in the previous studies, while low serum albumin within the normal range may have no such effect.

The present study had several limitations that should be considered. First, because this was a cross-sectional study, we could not confirm a causal relationship between chronic albumin status in blood and brain $\mathrm{A} \beta$ deposition. Some findings support the long-term stability of serum albumin level in healthy older adults. ${ }^{46-49}$ We also excluded individuals with severe medical conditions that could affect mental function. In addition, the results were not changed even when the individuals with decreased food intake were excluded. Together, our results may support a long-term causal effect of serum albumin on brain $A \beta$ deposition. Nevertheless, further longterm follow-up studies are required to clarify the causal relationships. In addition, the lack of repeated assessments of serum albumin level may have resulted in measurement errors because of diurnal variation. ${ }^{50}$ However, to minimize such errors, all blood samples for serum albumin measurement were obtained at the same time of the day (8-9 AM) in all participants.

The findings of present study suggest that low serum albumin may increase the risk of $\mathrm{AD}$ dementia by elevating amyloid accumulation. In terms of $\mathrm{AD}$ prevention, more attention needs to be paid to avoid low serum albumin level, even within the clinical normal range, by clinicians.

\section{Study funding}

This study was supported by a grant from the Ministry of Science, ICT, and Future Planning, Republic of Korea (grant NRF-2014M3C7A1046042) and a grant from the Korea Health Technology R\&D Project through the Korea Health Industry Development Institute, funded by the Ministry of Health \& Welfare, Republic of Korea (grant HI18C0630 \& HI19C0149).

\section{Disclosure}

The authors report no disclosures relevant to the manuscript. Go to Neurology.org/N for full disclosures.

\section{Publication history}

Received by Neurology May 14, 2019. Accepted in final form January 27, 2020.

Appendix 1 Authors

\begin{tabular}{lll}
\hline Name & Location & Contribution \\
\hline $\begin{array}{l}\text { Jee Wook } \\
\text { Kim, MD, } \\
\text { PhD }\end{array}$ & $\begin{array}{l}\text { Hallym University Dongtan } \\
\text { Sacred Heart Hospital, } \\
\text { Hwaseong, Republic of } \\
\text { Korea }\end{array}$ & $\begin{array}{l}\text { Study concept and design; } \\
\text { analysis and interpretation } \\
\text { of data; statistical analysis; } \\
\text { and drafting and critically } \\
\text { revising the manuscript for } \\
\text { intellectual content }\end{array}$ \\
\hline $\begin{array}{l}\text { Min Soo } \\
\text { Byun, } \\
\text { MD, PhD }\end{array}$ & Medical Research Center & $\begin{array}{l}\text { Acquisition, analysis, and } \\
\text { interpretation of data; } \\
\text { Seoul National University, } \\
\text { Republic of Korea }\end{array}$ \\
& & $\begin{array}{l}\text { critically revising the } \\
\text { manuscript for intellectual } \\
\text { content }\end{array}$
\end{tabular}

\begin{tabular}{lll}
\hline Jun Ho & Seoul National University & $\begin{array}{l}\text { Acquisition, analysis, and } \\
\text { interpretation of data; and } \\
\text { cee, MD }\end{array}$ \\
Hospitically revising the \\
manuscript for intellectual \\
content
\end{tabular}

\begin{tabular}{lll}
\hline $\begin{array}{l}\text { Dahyun } \\
\text { Yi, PhD }\end{array}$ & Medical Research Center & $\begin{array}{l}\text { Acquisition, analysis, and } \\
\text { interpretation of data; }\end{array}$ \\
& Reoul National University, & $\begin{array}{l}\text { statistical analysis; and } \\
\text { critically revising the } \\
\text { manuscript for intellectual } \\
\text { content }\end{array}$ \\
& &
\end{tabular}

So Yeon Chungnam National Acquisition, analysis, and

Jeon University Hospital, interpretation of data; and
Daejeon, Republic of Korea critically revising the manuscript for intellectual content

\begin{tabular}{|c|c|c|}
\hline $\begin{array}{l}\text { Bo Kyung } \\
\text { Sohn, MD }\end{array}$ & $\begin{array}{l}\text { Sanggye Paik Hospital, Inje } \\
\text { University College of } \\
\text { Medicine, Seoul, Republic of } \\
\text { Korea }\end{array}$ & $\begin{array}{l}\text { Acquisition, analysis, and } \\
\text { interpretation of data; and } \\
\text { critically revising the } \\
\text { manuscript for intellectual } \\
\text { content }\end{array}$ \\
\hline
\end{tabular}


Appendix 1 (continued)

\begin{tabular}{|c|c|c|}
\hline Name & Location & Contribution \\
\hline $\begin{array}{l}\text { Jun- } \\
\text { Young } \\
\text { Lee, MD, } \\
\text { PhD }\end{array}$ & $\begin{array}{l}\text { SMG-SNU Boramae Medical } \\
\text { Center, Seoul National } \\
\text { University College of } \\
\text { Medicine, Republic of Korea }\end{array}$ & $\begin{array}{l}\text { Acquisition, analysis, and } \\
\text { interpretation of data; and } \\
\text { critically revising the } \\
\text { manuscript for intellectual } \\
\text { content }\end{array}$ \\
\hline
\end{tabular}

Seong A SMG-SNU Boramae Medical Acquisition, analysis, and

Shin, BA Center, Seoul, Republic of interpretation of data; and Korea critically revising the manuscript for intellectual content

\begin{tabular}{|c|c|c|}
\hline $\begin{array}{l}\text { Yu } \\
\text { Kyeong } \\
\text { Kim, MD, } \\
\text { PhD }\end{array}$ & $\begin{array}{l}\text { SMG-SNU Boramae Medical } \\
\text { Center, Seoul, Republic of } \\
\text { Korea }\end{array}$ & $\begin{array}{l}\text { Acquisition, analysis, and } \\
\text { interpretation of data; and } \\
\text { critically revising the } \\
\text { manuscript for intellectual } \\
\text { content }\end{array}$ \\
\hline
\end{tabular}

Koung Mi Seoul National University

Kang, MD Hospital, Republic of Korea

Acquisition, analysis, and interpretation of data; and critically revising the manuscript for intellectual content

\begin{tabular}{ll}
\hline Chul-Ho & Seoul National University \\
Sohn, & Hospital, Republic of Korea \\
MD, PhD &
\end{tabular}

Acquisition, analysis, and interpretation of data; and critically revising the manuscript for intellectual content

\begin{tabular}{lll}
\hline Dong & Seoul National University & Study concept and design; \\
Young & Hospital, Seoul National & acquisition, analysis, and \\
Lee, MD, & University College of & interpretation of data; \\
PhD & Medicine, Republic of Korea & $\begin{array}{l}\text { statistical analysis; and } \\
\text { drafting and critically } \\
\end{array}$ \\
& & $\begin{array}{l}\text { revising the manuscript for } \\
\text { intellectual content }\end{array}$ \\
\end{tabular}

\section{Appendix 2 Coinvestigators}

Coinvestigators are listed at links.Iww.com/WNL/B134.

\section{References}

1. Cummings JL. Alzheimer's disease. N Engl J Med 2004;351:56-67.

2. Tobiansky R, Blizard R, Livingston G, Mann A. The Gospel Oak Study stage IV: the clinical relevance of subjective memory impairment in older people. Psychol Med 1995;25:779-786.

3. Braak H, Braak E. Neuropathological stageing of Alzheimer-related changes. Acta Neuropathol 1991;82:239-259.

4. Jack CR, Jr, Knopman DS, Jagust WJ, et al. Hypothetical model of dynamic biomarkers of the Alzheimer's pathological cascade. Lancet Neurol 2010;9:119-128.

5. Carter DC, Ho JX. Structure of serum albumin. Adv Protein Chem 1994;45: 153-203.

6. Biere AL, Ostaszewski B, Stimson ER, Hyman BT, Maggio JE, Selkoe DJ. Amyloid beta-peptide is transported on lipoproteins and albumin in human plasma. J Biol Chem 1996;271:32916-32922.

7. Kuo YM, Kokjohn TA, Kalback W, et al. Amyloid-beta peptides interact with plasma proteins and erythrocytes: implications for their quantitation in plasma. Biochem Biophys Res Commun 2000;268:750-756.

8. Zlokovic BV. Clearing amyloid through the blood-brain barrier. J Neurochem 2004; 89:807-811.

9. Stanyon HF, Viles JH. Human serum albumin can regulate amyloid-beta peptide fiber growth in the brain interstitium: implications for Alzheimer disease. J Biol Chem 2012;287:28163-28168.

10. Milojevic J, Raditsis A, Melacini G. Human serum albumin inhibits Abeta fibrillization through a "monomer-competitor" mechanism. Biophys J 2009;97:2585-2594.

11. Zuccala G, Marzetti E, Cesari M, et al. Correlates of cognitive impairment among patients with heart failure: results of a multicenter survey. Am J Med 2005;118: 496-502.

12. Mizrahi EH, Blumstein T, Arad M, Adunsky A. Serum albumin levels predict cognitive impairment in elderly hip fracture patients. Am J Alzheimers Dis Other Demen 2008; 23:85-90.
13. Llewellyn DJ, Langa KM, Friedland RP, Lang IA. Serum albumin concentration and cognitive impairment. Curr Alzheimer Res 2010;7:91-96.

14. Maes M, DeVos N, Wauters A, et al. Inflammatory markers in younger vs elderly normal volunteers and in patients with Alzheimer's disease. J Psychiatr Res 1999;33:397-405.

15. Kim TS, Pae CU, Yoon SJ, et al. Decreased plasma antioxidants in patients with Alzheimer's disease. Int J Geriatr Psychiatry 2006;21:344-348.

16. Xu WH, Dong C, Rundek T, Elkind MS, Sacco RL. Serum albumin levels are associated with cardioembolic and cryptogenic ischemic strokes: Northern Manhattan Study. Stroke 2014;45:973-978.

17. Phillips A, Shaper AG, Whincup PH. Association between serum albumin and mortality from cardiovascular disease, cancer, and other causes. Lancet 1989;2:1434-1436.

18. Byun MS, Yi D, Lee JH, et al. Korean brain aging study for the early diagnosis and prediction of Alzheimer's disease: methodology and baseline sample characteristics. Psychiatry Invest 2017;14:851-863.

19. Morris JC. The Clinical Dementia Rating (CDR): current version and scoring rules. Neurology 1993;43:2412-2414.

20. Lee DY, Lee KU, Lee JH, et al. A normative study of the CERAD neuropsychological assessment battery in the Korean elderly. J Int Neuropsychol Soc 2004;10:72-81.

21. Morris JC, Heyman A, Mohs RC, et al. The Consortium to Establish a Registry for Alzheimer's Disease (CERAD), part I: clinical and neuropsychological assessment of Alzheimer's disease. Neurology 1989;39:1159-1165.

22. Lee JH, Lee KU, Lee DY, et al. Development of the Korean version of the Consortium to Establish a Registry for Alzheimer's Disease assessment packet (CERAD-K): clinical and neuropsychological assessment batteries. J Gerontol B Psychol Sci Soc Sci 2002;57:P47-P53.

23. Vellas B, Guigoz Y, Garry PJ, et al. The Mini Nutritional Assessment (MNA) and its use in grading the nutritional state of elderly patients. Nutrition 1999;15:116-122.

24. Kuller LH, Eichner JE, Orchard TJ, Grandits GA, McCallum L, Tracy RP. The relation between serum albumin levels and risk of coronary heart disease in the Multiple Risk Factor Intervention Trial. Am J Epidemiol 1991;134:1266-1277.

25. Dik MG, Jonker C, Hack CE, Smit JH, Comijs HC, Eikelenboom P. Serum inflammatory proteins and cognitive decline in older persons. Neurology 2005;64:1371-1377.

26. Wenham PR, Price WH, Blandell G. Apolipoprotein E genotyping by one-stage PCR. Lancet 1991;337:1158-1159.

27. Park JC, Han SH, Yi D, et al. Plasma tau/amyloid-beta1-42 ratio predicts brain tau deposition and neurodegeneration in Alzheimer's disease. Brain 2019;142:771-786.

28. Reiman EM, Chen K, Liu X, et al. Fibrillar amyloid-beta burden in cognitively normal people at 3 levels of genetic risk for Alzheimer's disease. Proc Natl Acad Sci USA 2009; 106:6820-6825.

29. Choe YM, Sohn BK, Choi HJ, et al. Association of homocysteine with hippocampal volume independent of cerebral amyloid and vascular burden. Neurobiol Aging 2014; 35:1519-1525.

30. Westwood S, Baird AL, Hye A, et al. Plasma protein biomarkers for the prediction of CSF amyloid and tau and [(18)F]-Flutemetamol PET scan result. Front Aging Neurosci 2018;10:409.

31. Janssen L, Sobott F, De Deyn PP, Van Dam D. Signal loss due to oligomerization in ELISA analysis of amyloid-beta can be recovered by a novel sample pre-treatment method. MethodsX 2015;2:112-123.

32. Jack CR, Jr, Wiste HJ, Weigand SD, et al. Age-specific population frequencies of cerebral beta-amyloidosis and neurodegeneration among people with normal cognitive function aged 50-89 years: a cross-sectional study. Lancet Neurol 2014;13:997-1005.

33. Tsai JZ, Peng SJ, Chen YW, et al. Automated segmentation and quantification of white matter hyperintensities in acute ischemic stroke patients with cerebral infarction. PLoS One 2014;9:e104011.

34. Ng TP, Niti M, Feng L, Kua EH, Yap KB. Albumin, apolipoprotein E-epsilon4 and cognitive decline in community-dwelling Chinese older adults. J Am Geriatr Soc 2009;57:101-106.

35. Weiner DE, Bartolomei K, Scott T, et al. Albuminuria, cognitive functioning, and white matter hyperintensities in homebound elders. Am J Kidney Dis 2009;53:438-447.

36. Ota A, Kondo N, Murayama N, et al. Serum albumin levels and economic status in Japanese older adults. PLoS One 2016;11:e0155022.

37. Folsom AR, Ma J, Eckfeldt JH, Nieto FJ, Metcalf PA, Barnes RW. Low serum albumin: association with diabetes mellitus and other cardiovascular risk factors but not with prevalent cardiovascular disease or carotid artery intima-media thickness: the Atherosclerosis Risk in Communities (ARIC) Study Investigators. Ann Epidemiol 1995;5:186-191.

38. Sui M, Jia X, Yu C, et al. Relationship between hypoalbuminemia, hyperlipidemia and renal severity in patients with lupus nephritis: a prospective study. Cent Eur J Immunol 2014;39:243-252.

39. Cattin L, Bordin P, Fonda M, et al. Factors associated with cognitive impairment among older Italian inpatients: Gruppo Italiano di Farmacovigilanza nell'Anziano (G.I.F.A.). J Am Geriatr Soc 1997;45:1324-1330.

40. Hampel H, Kotter HU, Moller HJ. Blood-cerebrospinal fluid barrier dysfunction for high molecular weight proteins in Alzheimer disease and major depression: indication for disease subsets. Alzheimer Dis Assoc Disord 1997;11:78-87.

41. Jeandel C, Nicolas MB, Dubois F, Nabet-Belleville F, Penin F, Cuny G. Lipid peroxidation and free radical scavengers in Alzheimer's disease. Gerontology 1989;35: 275-282.

42. DeMattos RB, Bales KR, Cummins DJ, Paul SM, Holtzman DM. Brain to plasma amyloid-beta efflux: a measure of brain amyloid burden in a mouse model of $\mathrm{Alz}$ heimer's disease. Science 2002;295:2264-2267.

43. Boada M, Ortiz P, Anaya F, et al. Amyloid-targeted therapeutics in Alzheimer's disease: use of human albumin in plasma exchange as a novel approach for Abeta mobilization. Drug News Perspect 2009;22:325-339. 
44. Boada M, Lopez O, Nunez L, et al. Plasma exchange for Alzheimer's Disease Management by Albumin Replacement (AMBAR) trial: study design and progress. Alzheimers Dement 2019;5:61-69.

45. Boada M, Ramos-Fernandez E, Guivernau B, et al. Treatment of Alzheimer disease using combination therapy with plasma exchange and haemapheresis with albumin and intravenous immunoglobulin: rationale and treatment approach of the AMBAR (Alzheimer Management by Albumin Replacement) study. Neurologia 2016;31: 473-481.

46. Campion EW, deLabry LO, Glynn RJ. The effect of age on serum albumin in healthy males: report from the Normative Aging Study. J Gerontol 1988;43:M18-M20.
47. Leask RG, Andrews GR, Caird FI. Normal values for sixteen blood constituents in the elderly. Age Ageing 1973;2:14-23.

48. Reed AH, Cannon DC, Winkelman JW, Bhasin YP, Henry RJ, Pileggi VJ. Estimation of normal ranges from a controlled sample survey, I: sex- and age-related influence on the SMA 12-60 screening group of tests. Clin Chem 1972;18:57-66.

49. Misra DP, Loudon JM, Staddon GE. Albumin metabolism in elderly patients. J Gerontol 1975;30:304-306.

50. Andersen IB, Brasen CL, Christensen $\mathrm{H}$, et al. Standardised resting time prior to blood sampling and diurnal variation associated with risk of patient misclassification: results from selected biochemical components. PLoS One 2015;10:e0140475. 


\title{
Neurology
}

\author{
Serum albumin and beta-amyloid deposition in the human brain \\ Jee Wook Kim, Min Soo Byun, Jun Ho Lee, et al. \\ Neurology 2020;95;e815-e826 Published Online before print July 20, 2020 \\ DOI 10.1212/WNL.0000000000010005
}

This information is current as of July 20, 2020

Updated Information \& Services

References

Subspecialty Collections

Permissions \& Licensing

Reprints including high resolution figures, can be found at: http://n.neurology.org/content/95/7/e815.full

This article cites 50 articles, 9 of which you can access for free at: http://n.neurology.org/content/95/7/e815.full\#ref-list-1

This article, along with others on similar topics, appears in the following collection(s):

Alzheimer's disease

http://n.neurology.org/cgi/collection/alzheimers_disease

PET

http://n.neurology.org/cgi/collection/pet

Information about reproducing this article in parts (figures,tables) or in its entirety can be found online at:

http://www.neurology.org/about/about_the_journal\#permissions

Information about ordering reprints can be found online:

http://n.neurology.org/subscribers/advertise

Neurology ${ }^{\circledR}$ is the official journal of the American Academy of Neurology. Published continuously since 1951, it is now a weekly with 48 issues per year. Copyright Copyright ( 2020 The Author(s). Published by Wolters Kluwer Health, Inc. on behalf of the American Academy of Neurology.. All rights reserved. Print ISSN: 0028-3878. Online ISSN: 1526-632X.

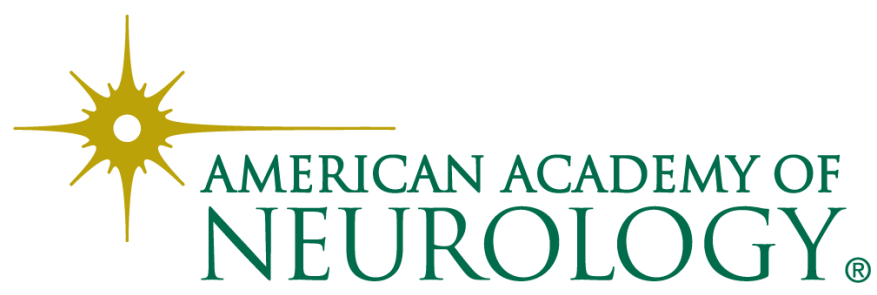

